\title{
ANTIOXIDANT ACTIVITIES OF ISOLATED COMPOUNDS FROM STEMS OF Mimosa invisa MART. EX COLLA
}

\author{
Rosane M. Aguiar \\ Departamento de Química e Exatas, Universidade Estadual do Sudoeste da Bahia, Campus Jequié, 45200-000 Jequié - BA, Brasil \\ Clayton Q. Alves, Jorge M. David*, Larissa C. de Rezende e Luciano S. Lima \\ Instituto de Química, Universidade Federal da Bahia, Campus Ondina, 40170-280 Salvador - BA, Brasil \\ Juceni P. David \\ Faculdade de Farmácia, Universidade Federal da Bahia, Campus Ondina, 40170-280 Salvador - BA, Brasil \\ Luciano P. de Queiróz \\ Departamento de Ciências Biológicas, Universidade Estadual de Feira de Santana, 44031-460 Feira de Santana - BA, Brasil
}

Recebido em 15/7/11; aceito em 28/9/11; publicado na web em 6/12/11

\begin{abstract}
This work describes the phytochemical study of stems of Mimosa invisa (Mimosaceae) and the evaluation of the antioxidant potential of isolated compounds. Cromatografic techniques were employed to isolate salicifoliol, pinoresinol, quercetin, quercetin-3-Orhamnopyranosyl, quercetin-3-O-arabinofuranosyl lupeol, $\beta$-amyrin, sitosterol, $p$-hydroxy coumaric acid, 4-hydroxy-3-methoxy benzaldehyde (vanillin), 4-hydroxy-3,5-dimethoxy benzaldehyde, 4-hydroxy-3-methoxy benzoic acid and 4',6,7- trimethoxy flavonol. The latter had been previously described but the spectrometric data shown indicated the structure required review. The antioxidant activity of the compounds was evaluated by the DPPH test and capability of NBT reduction by superoxide radicals. Quercetin glycosides showed lower antioxidant potential than quercetin and, salicifoliol was found to be more active than pinoresinol.
\end{abstract}

Keywords: Mimosa invisa; lignans; 4',6,7-trimethoxyflavonol.

\section{INTRODUCTION}

The genus Mimosa L. belonging to the family Leguminosae - Mimosoideae comprises between 300-400 species. The largest center of Mimosa diversity is the Brazil's central region but they are native to both Central and South America. In this central area of Brazil, the largest number of species occurs in the "Caatinga" and "Cerrado" habitats. The biome "cerrado" is considered an important center of endemism for plants of this genus. ${ }^{1}$ To date, few works have been published in the literature describing the chemical composition of Mimosa spp. Mimosa pudica L. can be considered representative of this genus based on studies dealing with the role of phenolic acids and the nictinasty behavior of the leaves. ${ }^{2}$ Other studies investigating this genus have indicated chalcones, flavanones and flavonols as the main phenolic compounds present in Mimosa. ${ }^{3}$

This paper reports the results of the phytochemical study of methanol extract of stem of Mimosa invisa Mart. ex Colla as well as the antioxidant evaluation of isolated compounds evaluated by DPPH and reduction of 3,3'-[3,3-dimethoxy-(1,1-biphenyl)-4,4diyl]-bis[2-(4-nitrophenyl)-5-phenyl-2H-tetrazolium chloride (NBT) by superoxide (SO) generated in vitro by the xanthinexanthine oxidase system. ${ }^{4}$

The chromatographic fractionation of the methanol extract of $M$. invisa afforded isolation of salicifoliol (1), pinoresinol (2), quercetin (3), quercetin-3-O-ramnopyranosyl (4), quercetin-3-Oarabinofuranosyl (5) and, 4',6,7-trimethoxy flavonol (6). Lupeol, $\beta$-amyrin, sitosterol, 4-hydroxy-3-methoxy benzaldehyde (vanillin), 4-hydroxy-3,5-dimethoxy benzaldehyde while $p$-hydroxycoumaric and 4-hydroxy-3-methoxy benzoic acids were also obtained from this plant.

*e-mail: jmdavid@ufba.br

\section{EXPERIMENTAL}

\section{General experimental procedures}

The NMR spectra were obtained on a Varian Gemini 2000 spectrometer operating at $300 \mathrm{MHz}\left({ }^{1} \mathrm{H}\right)$ and, $75 \mathrm{MHz}\left({ }^{13} \mathrm{C}\right)$, employing $\mathrm{CDCl}_{3}, \mathrm{CD}_{3} \mathrm{OD}$ and $\left(\mathrm{CD}_{3}\right)_{2} \mathrm{CO}$ as solvents and TMS as the internal standard. The MS analyses were carried out on a Shimadzu chromatographer mod. LCMS-2310 and GCMS-QP2010S. The UV/Vis spectra were registered on a Varian Cary I spectrophotometer. Conventional chromatographic methods were used in CC silica gel $60(63-200 \mu \mathrm{m})$ from Acros, Sephadex LH-20 (Pharmacia) and Poliamide 6 (50 $\mu \mathrm{m}$, Baker) and precoated Silica gel TLC plates (Whatman) were used to monitor the chromatographic fractions, revealed by iodine fumes and UV light $(254 / 366 \mathrm{~nm})$.

\section{Plant material}

The plant specimen was collected in December 2003 in the surroundings of Rio de Contas-BA, Brazil and, a sample (L. P. de Queiroz 7818, 16.v.2003) was deposited at Herbarium of Universidade Estadual de Feira de Santana, under number HUEFS 71543.

\section{Extraction and isolation of compounds}

The stems of M. invisa $(7.5 \mathrm{~kg})$ were extracted with $\mathrm{MeOH}(3 \mathrm{x}$ $10 \mathrm{~L}$ ). After filtration and removal of solvent, the resulting residue was partitioned with Hexane: $\mathrm{MeOH}, \mathrm{CHCl}_{3} / \mathrm{MeOH}: \mathrm{H}_{2} \mathrm{O}$ and EtOAc/ $\mathrm{H}_{2} \mathrm{O}$ yielding $30.0 \mathrm{~g}$ of hexane, $46.6 \mathrm{~g}$ of $\mathrm{CHCl}_{3}$ and $42.0 \mathrm{~g}$ of EtOAc phases, respectively.

The $\mathrm{CHCl}_{3}$ extract (12 g) was submitted to a CC over sílica gel 60 and eluted with hexane:EtOAc mixtures and the similar fractions were grouped by TLC employing UV light as the revelator (254/366 nm). The fraction ( $82 \mathrm{mg}$ ) eluted with hexane:EtOAc (8:2) was submitted 
to a PTLC employing silica gel $\mathrm{F}_{254}$ and eluted with $\mathrm{CHCl}_{3}: \mathrm{MeOH}$ (9:1) and this procedure allowed the obtention of pinoresinol 1 (15 $\mathrm{mg}$ ) and salicifoliol $2(12 \mathrm{mg})$. The fraction hexane:EtOAc 6:4 from main $\mathrm{CC}$ was submitted to $\mathrm{CC}$ using $\mathrm{CHCl}_{3}: \mathrm{MeOH}(9: 1 \rightarrow 4: 1)$ affording the compounds 4-hydroxy-3-methoxy benzaldehyde (vanillin, 18 $\mathrm{mg})$, 4-hydroxy-3,5-methoxy benzaldehyde (30 mg) and 4-hydroxy3-methoxy benzoic acid (51 mg). The fractions ( $232 \mathrm{mg}$ ) eluted with hexane:EtOAc (1:1) from the main CC were submitted to Sephadex LH-20 gel permeation using DCM:MeOH (1:1) and enabling the obtention of $15 \mathrm{mg}$ of compound 6 (4',6,7-trimethoxy flavonol).

The EtOAc phase $(15.0 \mathrm{~g})$ was submitted to $\mathrm{CC}$ on polyamide 6 ( $\phi 50 \mu \mathrm{m}$, Baker) eluted in reverse polarity order with $\mathrm{H}_{2} \mathrm{O}$, mixtures of $\mathrm{H}_{2} \mathrm{O}: \mathrm{MeOH}(9: 1,6: 4,1: 1)$ and $\mathrm{MeOH}$. The fractions obtained were further extracted with EtOAc. The $\mathrm{H}_{2} \mathrm{O}: \mathrm{MeOH}(1: 1)$ fraction was purified under flash silica gel $\mathrm{CC}$ using $\mathrm{CHCl}_{3}: \mathrm{MeOH}(4: 1)$ as the eluent, furnishing quercetin $(3,60 \mathrm{mg})$ and p-hydroxycoumaric acid (10 mg). The $\mathrm{H}_{2} \mathrm{O}: \mathrm{MeOH}(6: 4)$ fraction afforded quercetin-3-Oraminopyranosyl $(\mathbf{4}, 58 \mathrm{mg})$ and quercetin-3-O-arabinofuranosyl (5, $32 \mathrm{mg}$ ), respectively, after purification under flash silica gel CC eluted with $\mathrm{CHCl}_{3}: \mathrm{MeOH}(4: 1)$.

The hexane phase $(30 \mathrm{~g})$ was submitted to silica gel CC eluted with hexane:EtOAc 9:1, 7:3, 6:4, 1:1, and EtOAc. The similar fractions were collected after TLC revealed with a UV (254/366 nm) lamp and Liebermann-Burchard reagent. From these fractionsfractions, $\beta$-sisterol $(2,2 \mathrm{mg})$ as well as the mixture of lupeol and $\beta$-amyrin (30 mg), were obtained.

\section{Antioxidant activities}

\section{DPPH test}

The DPPH test was performed according to the described methodology. ${ }^{4}$ The radical scavenging ability was calculated by the formula $\% \mathrm{I}=\left[\left(\mathrm{Abs}_{\mathrm{B}}-\mathrm{Abs}_{\mathrm{A}}\right) / \mathrm{Abs}_{\mathrm{B}}\right] \times 100$ and the $\mathrm{IC}_{50}$ was established by the linear decreasing of inhibition percentage.

\section{Reduction of NBT}

In this test, the NBT was reduced by peroxide radical produced by xantine oxidase forming a blue compound which is related to the increase in absorbance at $\lambda 560 \mathrm{~nm}$. The methodology for performing this test was adapted from Fernandes et al.. ${ }^{5}$ For this experiment, a phosphate buffer solution $0.1 \mathrm{M}, \mathrm{pH} 7.8$ containing $0.2 \mathrm{mM}$ xanthine $0.6 \mathrm{mM}$ NBT was prepared. The solution of the enzyme xanthine oxidase was also prepared in $0.1 \mathrm{U} / \mathrm{mL}$ buffer solution. Before enzyme dissolution it was maintained for $30 \mathrm{~min}$ at $37^{\circ} \mathrm{C}$. The flavonoid solutions were prepared in 5 and $10 \mu \mathrm{M}$ concentrations by dissolving them in DMSO. The assay mixture was prepared directly in cuvettes with $3 \mathrm{~mL}$ of solution of $0.2 \mathrm{mM}$ of xanthine and $0.6 \mathrm{mM} \mathrm{NBT}$ and $100 \mu \mathrm{L}$ of standards to be tested on their concentrations. The test was carried out in duplicate. The reaction was initiated by adding $200 \mu \mathrm{L}$ of stock solution of xanthine oxidase. The cuvettes were incubated for $20 \mathrm{~min}$ at $37^{\circ} \mathrm{C}$, and the absorbance was read after this period. Also two blanks were prepared, one containing all reagents, except the antioxidants, with addition of equal volumes of DMSO, while the other blank was prepared with addition of all reagents except the enzyme, and with addition of the corresponding volume of buffer. Thus, the absorbance values obtained were assumed as control and blank, respectively. The percentage values of antioxidant activity were calculated based on the equation: $\mathrm{AA}=100-\left[\left(\mathrm{Abs}_{\text {sample }}-\mathrm{Abs}_{\text {blank }} / \mathrm{Abs}_{\text {control }}\right) \times 100\right]$. For determination of antioxidant activities the $\mathrm{IC}_{50}$ values were calculated from a graph of concentration $(\mu \mathrm{g} / \mathrm{mL})$ of sample vs. \%AA remaining.

Pinoresinol (1)

Amorphous solid. ${ }^{1} \mathrm{H}$ NMR $\left[300 \mathrm{MHz}, \mathrm{CD}_{3} \mathrm{OD}\right.$, multiplicity]:
3.11 (m, H-1 and H-5), 4.72 (d, $J=4$ Hz, H-2 and H-6), 3.81-4.25 (dd, $J=8$ and $6 \mathrm{~Hz}, \mathrm{H}-4$ and H-8), 6.84 (d, $J=2 \mathrm{HZ}, \mathrm{H}-2$ '), 6.84 (d, $J=8 \mathrm{~Hz}, \mathrm{H}-5$ '), 6.93 (dd, $J=8$ and $2 \mathrm{~Hz}, \mathrm{H}-6$ '), 3.97 (s, $\mathrm{OCH}_{3}$ ). ${ }^{13} \mathrm{C}$ NMR $\left[75 \mathrm{MHz}, \mathrm{CD}_{3} \mathrm{OD}\right]: 54.11(\mathrm{C}-1$ and $\mathrm{C}-5), 85.82(\mathrm{C}-2$ and C-6), 71.65 (C-4 and C-8), 132.54 (C-1'), 108.63 (C-1'), 146.66 (C-3'), 145.27(C-4'), 114.23(C-5'), 118.91 (C-6'), $55.92\left(\mathrm{OCH}_{3}\right){ }^{6}$

\section{Salicifoliol (2)}

Amorphous solid. EIMS (70 eV) m/z (rel.int.): $250\left[\mathrm{M}^{+}\right]$(35); 219 (10); 218 (8); 166 (19); 165 (25); 162 (82); 161 (73); 137 (55); 135 (45); 96 (100). ${ }^{1} \mathrm{H}$ NMR [300 MHz, $\mathrm{CD}_{3} \mathrm{OD}$, multiplicity]: 6.84 (d, $J=8 \mathrm{~Hz}, \mathrm{H}-1), 6.74$ (dd, $J=8$ and $2 \mathrm{~Hz}, \mathrm{H}-2), 6.81$ (d, $J=2 \mathrm{~Hz}$, H-4), 4.29 (m, H-6) 3.37 ( $\left.m, \mathrm{H}_{\mathrm{ax}}-7\right), 4.44$ (dd, $J=10$ and $7 \mathrm{~Hz}, \mathrm{H}_{\mathrm{ax}}$ -8), 4.12 (dd, $J=10$ and $\left.3 \mathrm{~Hz}, \mathrm{H}_{\mathrm{eq}}-8\right), 4.55$ (d, $\left.J=7 \mathrm{~Hz}, \mathrm{H}-11\right), 3.04$ (m, H-12), 4.01(s, $\left.\mathrm{OCH}_{3}\right) .{ }^{13} \mathrm{C}$ NMR [100 MHz, $\left.\mathrm{CD}_{3} \mathrm{OD}\right]:$ 114.45, (C-1), 119.11 (C-2), 146.03, (C-3), 108,54 (C-4), 179,04 (C-5), 69.9 (C-6), 46.0 (C-7), 69.8 (C-8), 86.1 (C-11), 48.2 (C-12), 130.03 (C13), $146.25(\mathrm{C}-14), 56.00\left(\mathrm{OCH}_{3}\right)^{6}$

\section{Quercetin (3)}

Amorphous solid. ${ }^{1} \mathrm{H}$ NMR and ${ }^{13} \mathrm{C}$ NMR data comparable with literature. $^{7}$

\section{Quercetin-3-0-rhanminoside (4)}

Yellow solid. MS (ESI) at $m / z 455[\mathrm{M}+\mathrm{Na}] .{ }^{1} \mathrm{H}$ NMR [300 MHz, $\mathrm{CD}_{3} \mathrm{OD}$, multiplicity]: $\delta 6.1(\mathrm{~d}, J=2 \mathrm{~Hz}, \mathrm{H}-6), 6.3(\mathrm{~d}, J=8 \mathrm{~Hz}$, H-8), 7.6 (d, $J=2$ Hz, H-2'), 6.8 (d, $J=8 \mathrm{~Hz}, \mathrm{H}-5$ '), 7.4 (dd, $J=8$ and 2 Hz, H-6'), 5.2 (s, H-1"), 3.9 (s, H-2"), 3.5 (m, H-3"), 3.1 (ind., H-4”). ${ }^{13}$ C NMR [100 MHz, CD OD]: $\delta 156.91$ (C-2), 134.78 (C-3), 178.24 (C-4), 162.09 (C-5), 98.53 (C-6), 164.01 (C-7), 93.51 (C-8), 157.35 (C-9), 104.70 (C-10), 121.53 (C-1'), 115.13 (C-2'), 144.81 (C-3'), 148.07 (C-4'), 115.78 (C-5'), 121.79 (C-6'), 101.75 (C-1"), 70.47 (C-2"), 71.11 (C-3"), 72.04 (C-4"), 70.31 (C-5"), 16.74 (C-6"). ${ }^{7}$

\section{Quercetin-3-ß-arabinofuranoside (5)}

Amorphous solid. ${ }^{1} \mathrm{H}$ NMR [300 $\mathrm{MHz}, \mathrm{CD}_{3} \mathrm{OD}$, multiplicity]: $\delta 6.2(\mathrm{~d}, J=2 \mathrm{~Hz}, \mathrm{H}-6), 6.4$ (d, $J=8 \mathrm{~Hz}, \mathrm{H}-8), 7.6$ (d, $J=2 \mathrm{~Hz}$, H-2'), 6.8 (d, $J=8 \mathrm{~Hz}, \mathrm{H}-5$ '), 7.5 (dd, $J=8$ and $2 \mathrm{~Hz}, \mathrm{H}-6$ '), 5.5 (d, $J=1.3 \mathrm{~Hz}, \mathrm{H}-1$ "), 4.1 (dd, $J=4 \mathrm{~Hz} \mathrm{H}-2$ "), 3.7 (dd, $J=6 \mathrm{~Hz}, \mathrm{H}-3$ "), 3.5 (m, J=4 and $6 \mathrm{~Hz}, \mathrm{H}-4$ "), 3.3 and 3.2 (m, H-5"). ${ }^{13} \mathrm{C}$ NMR [100 $\mathrm{MHz}, \mathrm{CD}_{3} \mathrm{OD}$ ]: $\delta 156.94$ (C-2), 133.42 (C-3), 179.53 (C-4), 160.86 (C-5), 98.45 (C-6), 163.82 (C-7), 93.34 (C-8), 156.42 (C-9), 103.92 (C-10), 120.96 (C-1'), 115.32 (C-2'), 144.86 (C-3'), 148.11 (C-4'), 115,32 (C-5'), 121.50 (C-6'), 107.63 (C-1"), 81.90 (C-2"), 76.62 (C3"), 85.65 (C-4"), $60.42(\mathrm{C}-5 "){ }^{8}$

\section{4',6,7-Trimethoxy flavonol (6)}

Amorphous solid. EIMS (70 eV) m/z: 328 [M+.] (100); 313 (7); 297 (5); 284 (15). ${ }^{1} \mathrm{H}$ NMR [300 MHz, $\mathrm{CDCl}_{3}$, multiplicity]: $\delta 7.3$ (s, H-5), 6.9 (s, H-8), 8.0 (d, J = 9 Hz, H-2'/ H-6'), 7.0 (d, $J=9$ Hz, H-3'/ H-5'), 3.9, 3.92, 4.0 (s, $\left.\mathrm{OCH}_{3}\right) .{ }^{13} \mathrm{C}$ NMR [75 MHz, $\left.\mathrm{CD}_{3} \mathrm{OD}\right]$ :

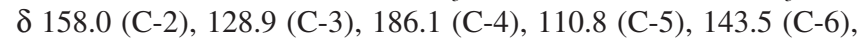
153.6 (C-7), 102.8 (C-8), 151.3 (C-9), 108.4 (C-10), 119.3 (C-1'), 121,1 (C-2'), 110.0 (C-3'), 156. 6 (C-4'), 110.0 (C-5'), 121.1 (C-6'), $56.5,56.2,56.0\left(\mathrm{OCH}_{3}\right)$.

\section{RESULTS AND DISCUSSION}

The benzoic and cinnamic acids derivatives were identified by NMR analysis and comparison with on-line databases (http://riodb01. ibase.aist.go.jp/sdbs/cgi-bin/cre_index.cgi?lang=eng, accessed in July 2011). The compounds $\mathbf{1}$ - 5 (Figure 1) were isolated as amorphous solids and identified by ${ }^{1} \mathrm{H}$ NMR and ${ }^{13} \mathrm{C}$ NMR data analyses and 
direct comparison with literature data. ${ }^{6-8}$ The presence of the lignan pinoresinol (1) and the derivative salicifoliol (2) in plants is known but this is the first description of the isolation of these compounds in the Mimosa genus.<smiles>COc1cc([C@@H]2OC[C@@H]3[C@H]2CO[C@H]3c2ccc(O)c(OC)c2)ccc1O</smiles><smiles>COc1cc([C@@H]2OC[C@H]3COC(=O)[C@@H]32)ccc1O</smiles><smiles>O=c1c(O)c(-c2ccc(O)c(O)c2)oc2cc(O)cc(O)c12</smiles>

3<smiles></smiles><smiles>COc1ccc(-c2oc3cc(OC)c(OC)cc3c(=O)c2O)cc1</smiles>

6

Figure 1. Isolated compounds (1 - 6) from Mimosa invisa

The flavonoid moieties of compounds 3-6 were established by ${ }^{1} \mathrm{H}$ and ${ }^{13} \mathrm{C}$ NMR data. The locations of rhamnopyranosyl and arabinofuranosyl groups at $\mathrm{C}-3$ in compounds $\mathbf{4}$ and $\mathbf{5}$, respectively, were recognized by $\mathrm{HMBC}$ spectra through correlations of anomer hydrogens and C-3 observed in each glycoside.

In ${ }^{1} \mathrm{H}$ NMR spectra of these compounds evidenced characteristic signals of ring A and B tetra substituted flavoanols. Furthermore, the ${ }^{1} \mathrm{H}$ NMR spectra of compounds $\mathbf{4}$ and $\mathbf{5}$ showed signals for the $O$-glycosyl bond. The spectrum of compound $\mathbf{4}$ showed signals suggesting the presence of $\alpha$-rhamnopyranoside at $\delta 0.93(J=5.7 \mathrm{~Hz}, \mathrm{~d})$ for the methyl group, $\delta 5.50(\mathrm{~d}, J=1.5 \mathrm{~Hz}, \mathrm{H}-1$ ") for the anomeric hydrogen, and multiplets at $\delta 3.93$ to $\delta 3.00 .{ }^{1} \mathrm{H}$ NMR spectrum of substance $(\mathbf{5})$ disclosed signals $\delta 5.47$ (s broad, $1 \mathrm{H})$ for the anomeric hydrogen and further signals at $\delta 4.15$ to $\delta 3.27$ of the remaining sugar hydrogens. Analysis of ${ }^{13} \mathrm{C}$ NMR spectra of these compounds corroborated the structure of the tetra substituted flavonoid as being quercetin. The ${ }^{13} \mathrm{C}$ NMR spectrum also allowed identification of the anomeric linkage and also the methyl group of rhamnoside moiety by signals at $\delta 101.7$ (C-1") and at $\delta 16.7$, in addition to four other signals for methine carbon characteristic of the sugar.

The ${ }^{13} \mathrm{C}$ NMR spectrum of $\mathbf{5}$ showed signals of anomeric C-1" at $\delta 108.8$ as well as three methine carbon signals corresponding to C-2", C-3" and C-4" ( $\delta 82.1,77.2$ and 85.5), and a signal of methylene carbon at $\delta 61.6$, by comparing with literature data, allowed the identification of arabinofuranoside attached at C-3. The location of glycosides at the hydroxyl groups of C-3 of compounds $\mathbf{4}$ and $\mathbf{5}$ were established by correlations observed on $\mathrm{HMBC}$ between the anomeric hydrogens of sugar and C-3.

The structure of compound $\mathbf{6}$ was determined as being flavonol by analysis of mono and bidimensional NMR data as well as the MS ion molecular. These analyses allowed proposal of the molecular formulae for 6 as being $\mathrm{C}_{18} \mathrm{H}_{16} \mathrm{O}_{6}$. The ${ }^{1} \mathrm{H}$ NMR spectrum of this

compound revealed the presence of two duplets at $\delta 8.0$ and $\delta 7.0$ $(J=9.0 \mathrm{~Hz})$ integrated for two hydrogens each, relative to flavonol 1,4-disubstituted B ring as well as, two singlets observed at $\delta 7.3$ and $\delta 6.9$ (1H each) indicating the 6,7 substituted A ring for this flavonoid. In addition, the presence of methoxyl groups and the broad singlet at $\delta 8.2(\mathrm{OH})$ suggested compound $\mathbf{6}$ was a 6,7,4'-substituted flavonol.

Analysis of ${ }^{13} \mathrm{C}$ NMR and DEPT 135 spectra confirmed the structure of compound $\mathbf{6}$ especially by signals recorded for four methine aromatic carbons and the signal of carbonyl at $\delta 185.2$ which is characteristic for flavonols. The structure identification the compound 6 as being the 4',6,7-trimethoxy flavonol was found through observation of correlations reported by the HMBC spectrum. The locations of the three methoxyl groups at C-4', C-6 and C-7 were established owing to the $J_{3}$ correlation between hydrogens of the methoxyl groups and the respective non-hydrogenated carbons (Figure 2). On the other hand, the correlations between $\mathrm{H}-5(\delta 7.3)$ and $\mathrm{C}-9(\delta$ 151.3) and C-7 $(\delta 153.6)$ and, H-8 ( $\delta 6.9)$ and C-7, C-9 and C-10 ( $\delta 108.4)$ were conclusive regarding the substitution pattern of the flavonol moiety.

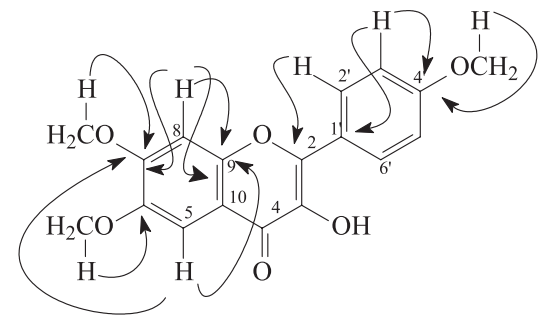

Figure 2. Key HMBC correlations observed for compound 6

Compounds $\mathbf{3}$ and $\mathbf{4}$ were previously detected by thin layer chromatography from leaves of $M$. invis $a^{9}$ but were firstly isolated and characterized in the present study. Moreover this is the first report of compound $\mathbf{5}$ in this genus.

The 4',6,7-trimethoxyflavonol (6) was previously detected among other flavonoids by LC-DAD-ESI-MS ${ }^{\mathrm{n}}$ in Artemisia annua (Compositae) extracts. ${ }^{10}$ In this previous study Han et al. employed the UV spectrum and its $\mathrm{MS}^{\mathrm{n}}$ spectrum ions to determinate the existence of three $\mathrm{CH}_{3}$ groups in the flavonoid skeleton. Based on the preliminary data, the structure of $\mathbf{6}$ was tentatively identified without isolation or full spectroscopic characterization of this new compound. Analyzing the MS data previously presented and assigned for $\mathbf{6}$ enabled us to conclude the given structure was not adequate since, the $[\mathrm{M}-\mathrm{H}]^{-}$observed was registered at $\mathrm{m} / \mathrm{z} 343$ and the expected molecular mass of this compound is 328 Daltons. The $\mathrm{MS}^{2}$ fragmentation spectra from the molecular ion furnished $\mathrm{m} / z .328$ (100) and $\mathrm{MS}^{3} \mathrm{~m} / z$ 313. These data indicated the compound present in $A$. annua was probably tetramethoxy derivative. Therefore, the published data and conclusions must be reviewed and the present work seems to be the first occurrence of 4',6,7-trimethoxyflavonol (6).

The antioxidant activities of compounds 1-5 were evaluated using DPPH scavenging assay and reduction of NBT by SO radical produced by xanthine oxidase. Quercetin shows the larger number of structural features that enhance their antioxidant activity, including the presence of two ortho hydroxyl groups in the B ring, a C2-C3 unsaturation with another hydroxyl group at $\mathrm{C}-3$, conjugation of the C-4 carbonyl group with hydroxyl group at C-5 and C-7 [10] and it was employed as standard. Among the evaluated flavonols quercetin presented the lowest IC50 values $(0.68$ and $22.22 \mu \mathrm{g} / \mathrm{mL})$ in both tests (Figures 3 and 4 ) typifying its greatest antioxidant potential. The compounds $\mathbf{4}$ and $\mathbf{5}$ show higher IC50 values than quercetin, and consequently lower antioxidant potential resulting from presence of a bulky group at C-3 reducing planarity and possibility of delocalization of electronic density of produced radical. The antioxidant 
and pro-oxidant activities of quercetin and derivates are known and proved including by in vivo experiments. ${ }^{11}$

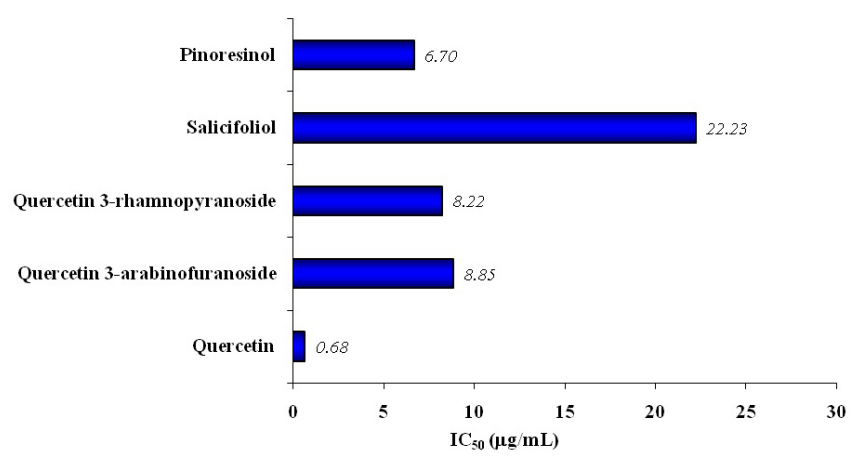

Figure 3. NBT reduction assays with compounds from Mimosa invisa

Among lignans, compound $\mathbf{1}$ showed, lowest IC50 values than compound $\mathbf{2}$ in both assays. These largest antioxidant activities of compound $\mathbf{1}$ are explained due to a higher number of phenol hydroxyl. There are a small number of lignans showing antioxidant activities. Pinoresinol (2) is considered one of the compounds responsible for the resistance to oxidative deterioration of virgin olive oil, but, the evaluation of its activity hs been by in vitro experiments. ${ }^{12}$

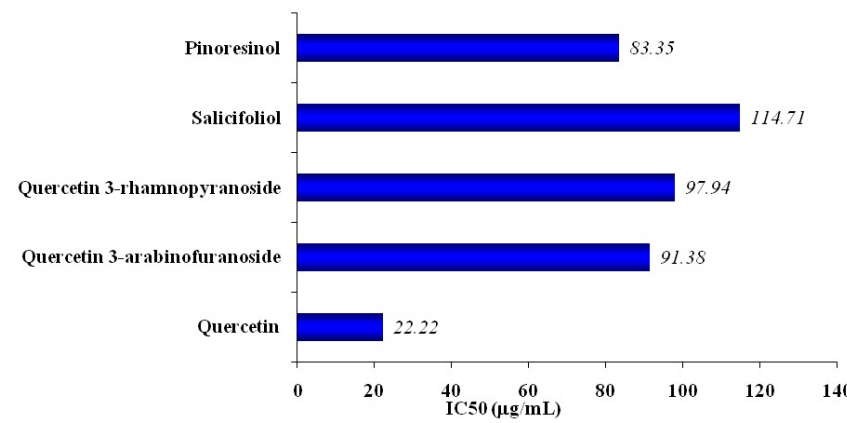

Figure 4. DPPH scavenging radicals assays with compounds from Mimosa invisa

\section{ACKNOWLEDGMENTS}

The authors are grateful to the CNPq, FAPESB and PRONEX for providing fellowships and grants.

\section{REFERENCES}

1. Flores-Cruz, M.; Santana-Lira, H. D.; Koch, S. D.; Grether, R.; Syst. Bot. 2004, 29, 892; Simon, M. F.; Hay, J. D.; Austral Ecology 2003, 28, 315.

2. Ueda, M.; Yamamura, S.; Tetrahedron Lett. 1999, 40, 2981; Ueda, M.; Yamamura, S.; Tetrahedron 1999, 55, 10937.

3. Dominguez, X. A.; Garcia, S. G.; Williams, H. J.; Ortiz, C.; Scott, A. I.; Reibenspies, J. H.; J. Nat. Prod. 1989, 52, 864; Ohsaki, A.; Yokoyama, R.; Miyatake, H.; Fukuyama, Y.; Chem. Pharm. Bull. 2006, 54, 1728; Yuan, K.; Jia, A.; Lu, J.; Zhongguo Zhongyao Zazhi 2006, 31, 1029.

4. She, G. M.; Zhang, Y. J.; Yang, C. R.; Chem. Biodivers. 2009, 6, 875; Alves, C. Q.; David, J. M.; David, J. P.; Bahia, M. V.; Aguiar, R. M.; Quim. Nova 2010, 33, 2202.

5. Fernandes, A. S.; Gaspar, J.; Cabral, M. F.; Caneiras, C.; Guedes, R.; Rueff, J.; Castro, M.; Costa, J.; Oliveira, N. G.; J. Inorg. Biochem. 2007, 101,849

6. El-Hassan, A.; El-Sayed, M.; Hamed, A. I.; Rhee, I. K.; Ahmed, A. A.; Zeller, K. P.; Verpoorte, R.; Fitoterapia 2003, 74, 1840; Gonzalez, A. G.; Estevez-Reyes, R.; Mato. C.; J. Nat. Prod. 1989, 52, 1139; Marchand, P. A.; Zajicek, J.; Lewis, N. G.; Can. J. Chem. 1997, 75, 840.

7. Meira, M.; David, J. M.; David, J. P.; Araújo, S. V.; Regis, T. L.; Giulietti. A. M.; de Queiróz, L. P.; Quim. Nova 2008, 31, 751; David, J. M.; Cruz, F. G.; Guedes, M. L. S.; Chávez, J. P.; J. Braz. Chem. Soc. 1996, 7, 115.

8. Metwally, A. M.; Omar, A. A.; Harraz, F. M.; El Sohafy, S. M.; Pharmacogn. Mag. 2010, 6, 212; Zhang, X.; Thuong, P. T.; Jin, W.Y.; Su, N. D.; Sok, D. E.; Bae, K.H.; Kang, S. S.; Arch. Pharm. Res. 2005, 28, 22.

9. Umi Kalsom, Y.; Noriha, A.; Baki, B.; Khairuddin, I.; Faridah, A.; Aspollah, S.; Biochem. Syst. Ecol. 2003, 31, 443.

10. Han, J.; Ye, M.; Qiao, X.; Xu, M.; Wang, B.; Guo, D-A.; J. Pharm. Biomed. Anal. 2008, 47, 516.

11. Mikstacka, R.; Rimando, A. M.; Ignatowicz, E.; Plant Food Hum. Nutr. 2010, 65, 57; Papiez, M. A.; Cierniak, A.; Krysciak, W.; Bzowska, M.; Taha, H. M.; Jozkowicz, A.; Piskula, M.; Food Chem. Toxicol. 2008, 46, 3053.

12. Carrasco-Pancorbo, A.; Cerratani, L.; Bendini, A.; Segura-Carretero, A.; Del Carlo, M.; Gallina-Toshci, T.; Lercker, G.; Compagnone, D.; Fenandez-Guitierrez, A.; J. Agric. Food Chem. 2005, 53, 8918; David, J. M.; Barreiros, A. L. B. S.; David, J. P.; Pharm. Biol. 2004, 42, 36. 